\title{
Relationships between growth rate, carcass composition, feed intake, feed conversion ratio and income in four biological types of cattle ${ }^{(1)}$
}

\author{
R. HANSET* ${ }^{*}$ C. MICHAUX* and A. STASSE** \\ * Chaire de Génétique, Faculté de Médecine Vétérinaire (U. Lg), \\ 45, rue des Vétérinaires, B-1070 Bruxelles (Belgique) \\ ** Ministère de l'Agriculture, Station de Sélection Bovine, \\ 12, rue des Champs-Elysées, B-5300 Ciney (Belgique)
}

\begin{abstract}
Summary
The relations between growth rate, carcass composition, feed intake, feed conversion ratio and income are investigated on bulls entered in Station at the age of one month and tested from 7 to 12 months of age, belonging to four biological types : 1) Belgian Blue bulls of the double-muscled type (DM), $(\mathrm{n}=622) ; 2)$ crossbred sons of DM sires out of Friesian dams (DM $\times$ FR), $(n=94) ; 3)$ similar sons but out of MRY dams $(D M \times M R Y),(n=20) ; 4)$ Belgian Blue bulls of conventional type (CONV), $(n=236)$.
\end{abstract}

For the biological as for the economical traits considered, the double-muscled type was quite distinct from the other types. In comparison with the conventional animals, the double-muscled ones had their feed intake reduced by $6.5 \mathrm{p}$. 100, their feed conversion ratio reduced by $8.7 \mathrm{p} .100$, their dressing-out percentage increased by $8 \mathrm{p}$. 100 , their percent lean in the $7^{\text {th }}$ ribcut increased by $20 \mathrm{p} .100$, their percent fat in the same ribcut lowered by $42 \mathrm{p} .100$. For the year 1980 , the selling price of the double-muscled exceeded that of the conventional by 57 p. 100 and their net income was 3.25 times higher.

The coefficients of determination $\left(R^{2}\right)$ of feed intake and of feed conversion ratio by initial weight, daily gain and carcass composition criteria were computed within each biological type. These traits were considered singly and in combination. It was found that, within biological types, the carcass traits were of minor importance in the determination of feed intake or of feed conversion. A covariance analysis showed that mean feed intake adjusted for initial weight and daily gain, was significantly different, among biological types, suggesting different maintenance requirements and especially lower maintenance requirement in the double-muscled bull. Determination of selling price and of net income by growth and carcass traits were also investigated.

Genetic parameters, heritabilities and genetic correlations, were estimated « within the doublemuscled type ". These parameters were used to calculate the genetic responses to selection on daily gain, ratio of gain to initial weight, final weight, feed conversion ratio, net income, selection indices combining, as measured variables, either daily gain and feed intake (index I) or daily gain and initial weight (index II). All these selection criteria with the exception of final weight gave as direct or correlated responses, higher net income, reduced initial weight, moderately increased final weight. As an improvement of gain relative to weight brings the best financial return after fattening, the problems of the genetic bending of the growth curve and of the choice of the best selection criteria are discussed.

Key words : Growth, feed conversion ratio, carcass composition, genetic parameters, selection, double-muscled cattle.

(1) This work is supported by the "Institut pour l'encouragement de la Recherche scientifique dans l'Industrie et l'Agriculture » (I.R.S.I.A.). 


\begin{abstract}
Résumé
Relations entre la vitesse de croissance, la composition de carcasse, la consommation alimentaire, l'indice de consommation et le revenu dans quatre types biologiques bovins
\end{abstract}

Les relations entre la vitesse de croissance, la composition de carcasse, la consommation alimentaire, l'indice de consommation et le revenu ont été analysées chez des taureaux entrés en station à l'âge d'un mois et contrôlés entre 7 et 12 mois. Ces taureaux appartiennent à 4 types biologiques : 1) Blanc-Bleu Belge du type culard $(\mathrm{DM})(\mathrm{n}=622) ; 2)$ croisés de pères DM et de mères Frisonnes $(\mathrm{DM} \times \mathrm{FR})(\mathrm{n}=94) ; 3)$ croisés de pères $\mathrm{DM}$ et de mères MRY $(\mathrm{DM} \times \mathrm{MRY})$ $(\mathrm{n}=20)$; 4) Blanc-Bleu Belge du type mixte (CONV) $(\mathrm{n}=236)$.

Pour les caractères biologiques et économiques envisagés, le type culard se distingue nettement des 3 autres types. Comparés aux animaux du type mixte, les animaux du type culard ont une consommation alimentaire moindre $(-6,5$ p. 100), un indice de consommation plus faible $(-8,7 \mathrm{p} .100)$, un rendement à l'abattage supérieur $(+8 \mathrm{p} .100)$, un pourcentage plus élevé de muscle dans le $7^{\mathrm{c}}$ morceau monocostal $(+20 \mathrm{p} .100)$, un pourcentage plus faible de graisse ( -42 p. 100). Pour l'année 1980, le prix de vente (au kilo de poids vif) de l'animal culard dépassait de 57 p. 100 celui de l'animal mixte et le revenu net correspondant à la période de contrôle ( 7 à 12 mois) était multiplié par le facteur 3,25 .

Les coefficients de détermination $\left(\mathrm{R}^{2}\right)$ de la consommation alimentaire et de l'indice de consommation par le poids initial, le gain de poids quotidien et les critères de composition de carcasse ont été calculés, séparément pour chaque type biologique. Intra type, les caractères de carcasse se sont révélés d'importance mineure dans la détermination de la consommation alimentaire et de l'indice de consommation. Une analyse de covariance a montré que les consommations alimentaires moyennes, ajustées pour le poids initial et le gain de poids quotidien, étaient significativement différentes, entre types biologiques, ce qui suggère des besoins d'entretien différents entre types biologiques et en particulier des besoins d'entretien plus faibles chez le taureau culard. La détermination du prix de vente et du revenu net par les caractères de croissance et carcasse a été étudiée.

Les paramètres génétiques, héritabilités et corrélations génétiques, ont été estimés à l'intérieur du type culard. Ces paramètres furent utilisés pour calculer les réponses génétiques attendues en cas de sélection sur : le gain de poids journalier, le rapport gain/poids initial, le poids final, l'indice de consommation, le revenu net, des indices de sélection utilisant comme caractères mesurés soit le gain journalier et la consommation alimentaire (index I) soit le gain journalier et le poids initial (index II).

Tous ces critères de sélection, à l'exception du poids final, ont donné comme réponses directes ou indirectes, un revenu net plus élevé, un poids initial plus faible, un poids final pas ou peu modifié. Comme une amélioration du gain par rapport au poids procurait le meilleur revenu, la possibilité d'une modification génétique de la courbe de croissance est discutée ainsi d'ailleurs que la question du choix des meilleurs critères de sélection.

Mots clés : Croissance, indice de consommation, composition de carcasse, paramètres génétiques, sélection, bovins culards.

\title{
I. Introduction
}

In addition to viability and morbidity, growth rate, carcass composition and food consumption are factors determining profitability in beef production. The way these factors contribute to the Net Added Value after fattening is illustrated in figure 1.

The Added Value is obtained by multiplying the weight gain by the selling price per kilo liveweight, the latter being determined to some extent by the body composi- 
tion. The selling price is also influenced by the final weight. In our conditions, the market penalizes underweight animals. Feed intake reflects the maintenance requirements (metabolic weight) and the needs for liveweight gain including variations of composition. The Net Added Value is given by the Added Value from which the food costs have been subtracted. In so doing, it is assumed that the price is the same at the beginning as at the end of the fattening period. Feed conversion ratio expressed by the ratio of food consumption to gain measures « gross efficiency " since it includes both a maintenance and a growth component.

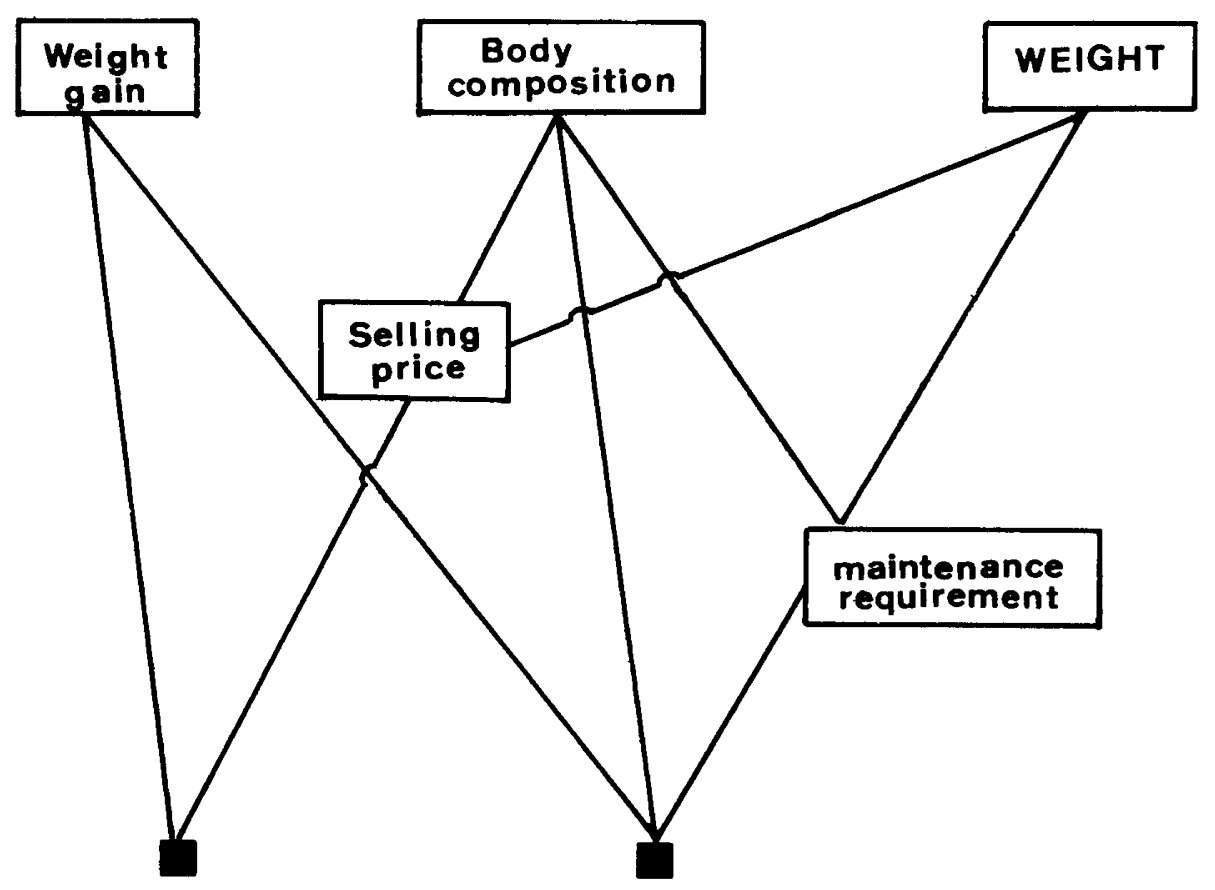

Added Value minus Food Costs $=$ Net Added Value

Fig. 1

Contribution of weight, body composition and weight gain to the Net Added Value after fattening.

The purpose of this paper is to study the interrelationships between growth rate, carcass composition, feed intake and feed efficiency « among " and "within " four biological types characterized by different carcass compositions and different ingestion capacities and to discuss the problem of the choice of the best selection criterion. 


\section{Material and methods}

The material (progeny-test data) consists of 972 bulls belonging to four biological types : 1) Belgian Blue bulls of the double-muscled type (DM) $(n=622) ; 2)$ crossbred sons of DM sires out of Friesian dams $(D M \times F R)(n=94) ; 3)$ similar sons but out of MRY (Meuse-Rhin-Yssel) dams (DM $\times$ MRY) $(\mathrm{n}=20) ; 4)$ Belgian Blue bulls of the conventional type $(\mathrm{CONV})(\mathrm{n}=236)$. Their distribution across years is shown in table 1.

TABLE 1

Distribution of the 972 bulls across biological types and years.

\begin{tabular}{|c|c|c|c|c|c|c|c|c|c|}
\hline \multirow{2}{*}{ Biological type } & \multicolumn{8}{|c|}{ Year } & \multirow{2}{*}{ Total } \\
\hline & 78 & 79 & 80 & 81 & 82 & 83 & 84 & 85 & \\
\hline $\begin{array}{l}\text { Double-muscled (DM) } \\
\text { (Belgian Blue) }\end{array}$ & $\begin{array}{c}55 \\
(10)\end{array}$ & $\begin{array}{l}62 \\
(11)\end{array}$ & $\begin{array}{c}85 \\
(10)\end{array}$ & $\begin{array}{l}123 \\
(11)\end{array}$ & $\begin{array}{l}128 \\
(15)\end{array}$ & $\begin{array}{l}78 \\
(6)\end{array}$ & $\begin{array}{c}91 \\
(10)\end{array}$ & & 622 \\
\hline $\begin{array}{l}\text { Crossbreds } \ldots \ldots \ldots \\
(\text { Belgian Blue sires } \\
(\text { DM) } \times \text { Friesian dams) }\end{array}$ & & & & $\begin{array}{l}21 \\
(3)\end{array}$ & & & & $\begin{array}{l}73 \\
(6)\end{array}$ & 94 \\
\hline $\begin{array}{l}\text { Crossbreds . . . . . } \\
\text { (Belgian Blue sires (DM) } \\
\times M R Y \text { dams) }\end{array}$ & & & & & & & & $\begin{array}{l}20 \\
(9)\end{array}$ & 20 \\
\hline $\begin{array}{l}\text { Conventional (CONV) . . } \\
\text { Belgian Blue }\end{array}$ & $\begin{array}{c}72 \\
(10)\end{array}$ & $\begin{array}{c}83 \\
(11)\end{array}$ & $\begin{array}{l}38 \\
(3)\end{array}$ & $\begin{array}{l}18 \\
(5)\end{array}$ & $\begin{array}{l}15 \\
(8)\end{array}$ & $\begin{array}{c}3 \\
(3)\end{array}$ & $\begin{array}{c}7 \\
(6)\end{array}$ & & 236 \\
\hline
\end{tabular}

(In parentheses, the number of sires. In 1978 and 1979, the conventional and the double-muscled animals had the same sires, all of the DM type. Afterwards, the conventional animals had sires of the conventional or dualpurpose type).

Animals enter the Test Station at the age of one month (during the months March, April, May): After a stay of 2 months in nursery, the animals were fed ad libitum with a first concentrate and straw. From the age of 5 months to the end of the testing period, they received a second concentrate ad libitum and had free access to straw from a rack. The composition of this second concentrate was as follows : cotton seed cake : 5 p. 100 ; linseed cake : 5 p. 100 ; coconut cake : 5 p. 100 ; soya been meal (extr.) : 6 p. 100 ; sugar beet pulp, dried : 40 p. 100 ; molasses : 4.5 p. 100 ; barley flake : 15 p. 100 ; wheat (fine middlings-bran) : 10 p. 100 ; rice meal : 5 p. 100 ; minerals and vitamins : 4.5 p. 100 ; digestible crude proteins : 14 p. 100 . The dry matter content was $88 \mathrm{p} .100$ and the energy content of $1 \mathrm{~kg}$ dry matter was $2.8 \mathrm{M}$.Cal. ME, as estimated from the ARC tables.

The bulls, allotted in groups of five according to age, were kept in loose-housing on straw bedding. The individual feeding of the concentrate was achieved by an electronically activated locking mechanism of the access door. The ingestion of straw was not recorded. The testing period started at 7 months and ended at 12 months, the 
age of slaughter. The standard deviation of initial and final ages was about 5 days. The data were adjusted to the ages of 210 and 365 days. There was no fasting period prior to slaughter. All the animals were slaughtered in the same slaughter-house; they left the Station on Tuesday (last weighing), were slaughtered on Wednesday morning, the carcasses weighted on Thursday. The dressing-out percentage was computed as the ratio of carcass weight (cold) to final weight at the Station (average of 2 weighings). The $7^{\text {th }}$ ribcut was taken and divided into lean, fat and bone.

Feed conversion ratio was expressed as the ratio of feed intake on gain. The selling price per kilo liveweight was determined by the same person throughout the entire period taking into account the weight, the conformation, the degree of finishing and the market trends. Net Added Value or more simply Net Income for the period 7 to 12 months was computed as follows separately for each year : gain $\times$ selling price - food consumption $\times$ food price.

The means corresponding to the 4 biological types were computed across years and sires, and compared by the Duncan's multiple range test (DUNCaN, 1955).

The amounts of variation in feed intake, feed conversion ratio, selling price and net income accounted for by growth carcass criteria were measured by the coefficients of determination $\left(\mathrm{R}^{2}\right)$ computed from the adjustments of simple and multiple regression equations.

A comparison of the 4 biological types for feed intake was made by covariance analysis, initial weight and daily gain being the covariates. In this kind of analysis, 3 tests are carried out : a test of equality" of slopes, a test of zero slope and a test of equality of adjusted means (SNEDECOR \& Cochran, 1980).

Genetic parameters were estimated within the double-muscled type on 505 animals born from 52 sires of the double-muscled type. In this analysis, sires were nested within years (years 1981 to 1984) and the components of variance and covariance, « between sires within years " were estimated. The Least-Squares and Maximum Likelihood Computer Program (LSML76) was used for this analysis (HARvey, 1977).

\section{Results}

\section{A. Biological traits}

The means across years of the different characteristics are given in table 2 for each biological type.

Significant differences between biological types are found for : weight at 7 months (initial weight), daily feed consumption, feed conversion ratio, dressing-out percentage, composition of the $7^{\text {th }}$ ribcut. In comparison with the conventional animals, the doublemuscled ones have their feed intake reduced by $6.5 \mathrm{p} .100$ their feed conversion ratio decreased by 8.7 p. 100 their dressing-out percentage increased by 8 p. 100 , their percent lean in the $7^{\text {th }}$ ribcut increased by $20 \mathrm{p}$. 100 , their percent fat decreased by 40 p. 100.

Feed consumption is highest in the crossbreds but these were not tested at the same time as the other types. 
TABLE 2

Growth, feed intake, feed conversion and carcass characteristics of one year old bulls of four biological types.

\begin{tabular}{|c|c|c|c|c|c|c|c|c|}
\hline \multirow{3}{*}{ Biological type } & \multirow{2}{*}{\multicolumn{2}{|c|}{$\begin{array}{c}\text { Belgian Blue } \\
\text { double-muscled } \\
\mathrm{n}=622\end{array}$}} & \multicolumn{4}{|c|}{$\begin{array}{l}\text { Crossbred from } \\
\text { Belgian Blue sires } \\
\text { (DM type) }\end{array}$} & \multirow{2}{*}{\multicolumn{2}{|c|}{$\begin{array}{c}\text { Belgian Blue } \\
\text { conventional } \\
\mathrm{n}=236\end{array}$}} \\
\hline & & & \multicolumn{2}{|c|}{$\begin{array}{c}\times \text { Friesian } \\
\text { dams }(n=94)\end{array}$} & \multicolumn{2}{|c|}{$\begin{array}{c}\times M . R . Y . \\
\text { dams }(n=20)\end{array}$} & & \\
\hline & $\overline{\mathbf{x}}$ & $\mathbf{s}$ & $\overline{\mathbf{x}}$ & $\mathbf{s}$ & $\overline{\mathbf{x}}$ & $\mathbf{s}$ & $\overline{\mathbf{x}}$ & $\mathbf{s}$ \\
\hline $\begin{array}{l}\text { Initial weight }(\mathrm{kg}) \ldots \ldots \\
\text { (at } 7 \text { months) }\end{array}$ & $272.5^{\mathrm{a}}$ & 35.0 & $278.0^{\mathrm{ab}}$ & 24.9 & $281.2^{\mathrm{ab}}$ & 26.2 & $287.9^{b}$ & 27.6 \\
\hline $\begin{array}{l}\text { Final weight }(\mathrm{kg}) \\
\text { (at } 12 \text { months) }\end{array}$ & 471.3 & 45.0 & 480.1 & 38.1 & 485.4 & 34.0 & 482.8 & 41.7 \\
\hline Aver. daily gain (kg) & 1.29 & 0.16 & 1.30 & 0.14 & 1.31 & 0.12 & 1.26 & 0.17 \\
\hline $\begin{array}{l}\text { Daily feed consumption . . } \\
\text { (kg) }\end{array}$ & $7.48^{\mathrm{a}}$ & 0.84 & $8.62^{c}$ & 0.75 & $8.69^{c}$ & 0.73 & $8.00^{b}$ & 0.81 \\
\hline $\begin{array}{l}\text { Feed conv. ratio } \\
(\mathrm{kg} \text { feed } / \mathrm{kg} \text { gain })\end{array} \cdots$ & $5.85^{\mathrm{a}}$ & 0.72 & $6.66^{b}$ & 0.62 & $6.67^{b}$ & 0.65 & $6.41^{b}$ & 0.79 \\
\hline Dressing out-percentage . . & $64.81^{\mathrm{a}}$ & 1.50 & $59.39^{c}$ & 1.30 & $59.97^{b}$ & 1.15 & $59.98^{b}$ & 1.55 \\
\hline $\begin{array}{l}\text { Composition of the } \\
7^{\text {th }} \text { ribcut : } \\
\text { Lean } \% \quad \ldots \ldots\end{array}$ & $70.48^{a}$ & 3.04 & $57.88^{a}$ & 3.44 & $61.13^{c}$ & 2.94 & $58.73^{b}$ & 3.66 \\
\hline Fat $\%$ & $12.80^{\mathrm{a}}$ & 2.68 & $22.24^{b}$ & 3.98 & $18.87^{\mathrm{c}}$ & 3.84 & $22.10^{\mathrm{b}}$ & 3.81 \\
\hline Bone $\% \ldots \ldots$ & $16.71^{\mathrm{a}}$ & 1.53 & $19.86^{\mathrm{c}}$ & 1.96 & $19.99^{\mathrm{c}}$ & 1.90 & $19.17^{b}$ & 1.70 \\
\hline
\end{tabular}

$\overline{\mathbf{x}}=$ mean $; \mathbf{s}=$ Standard deviation.

Means with the same letter are not significantly different $(P<0.05)$ between biological types.

The biological types, other than the double-muscled type, are sirilar for initial weight and feed conversion ratio. Between the crossbreds, those from MRY cows had better dressing-out percentage, lean and fat contents.

The relative locations of the 4 biological types regarding feed intake or feed conversion ratio and body composition are illustrated in figure 2 (dressing-out percentage) and in figure 3 (percent lean in the $7^{\text {th }}$ ribcut).

Unweighted regression lines have been drawn across the points. Their slopes are : 1) regression on dressing-out percentage (DO) : feed intake $=-0.1937 \mathrm{~kg} / \mathrm{p} .100 \mathrm{DO}$; feed conversion $=-0.1459 \mathrm{~kg} / \mathrm{p}$. $100 \mathrm{DO} ; 2)$ regression on percent lean : feed inta$\mathrm{ke}=-0.0758 \mathrm{~kg} / \mathrm{p} .100$ lean $;$ feed conversion $=-0.0598 \mathrm{~kg} / \mathrm{p} .100$ lean).

The coefficients of determination $\left(R^{2}\right)$ of feed intake and of feed conversion ratio by initial weight, daily gain, dressing-out percentage and percent lean in the $7^{\text {th }}$ ribcut, considered alone or in different combinations, are given in table 3 (feed intake) and 


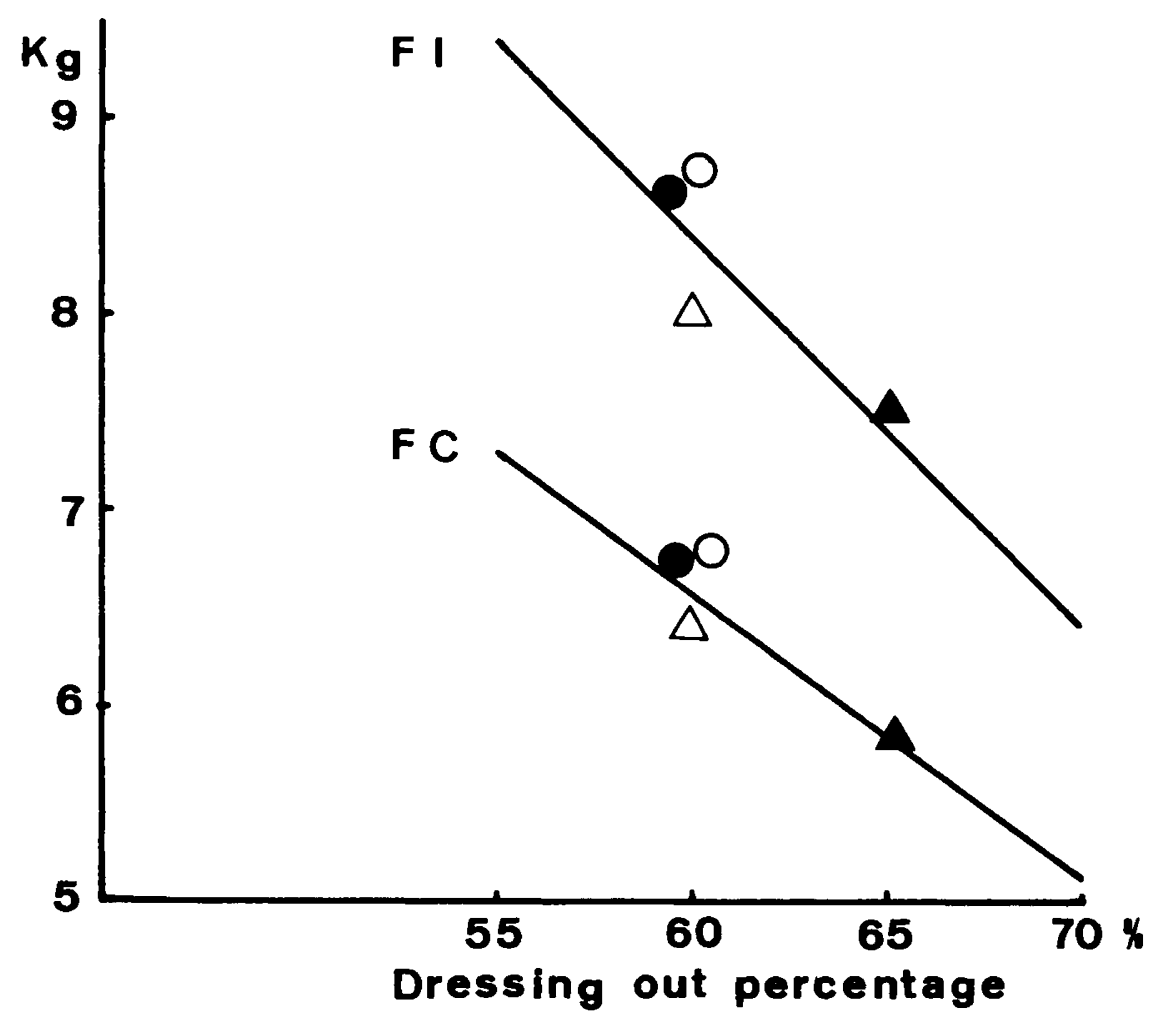

FIG. 2

Regression of the feed intake (FI) and feed conversion (FC) on dressing-out percentage, across biological types:

A : Belgian Blue, double muscled (DM) ;

: Crossbred Belgian Blue DM $\times$ Friesian;

$O$ : Crossbred Belgian Blue DM $\times$ MRY;

$\triangle:$ Belgian Blue, conventional (CONV).

table 4 (feed conversion). Within each of the 4 biological types, feed intake during the test period is strongly influenced by initial weight. The same is true for daily gain although it is not significant within the DM $\times$ MRY type. On the contrary, the criteria of body composition, as dressing-out percentage and percent lean, have a small influence, if any, on feed intake. The coefficient of determination is substantially increased if initial weight and daily gain are included together in the regression equation. On the other hand, the addition of a criterion of body composition brought no further increase of the coefficient of determination.

If one considers table 4, the same picture emerges. The feed conversion ratio was also significantly influenced by initial weight (positively) and by daily gain (negatively). Nevertheless, daily gain was more closely related to feed conversion ratio than initial weight and this is true for each biological type. Once again, within biological type, the criteria of body composition were of minor importance. 


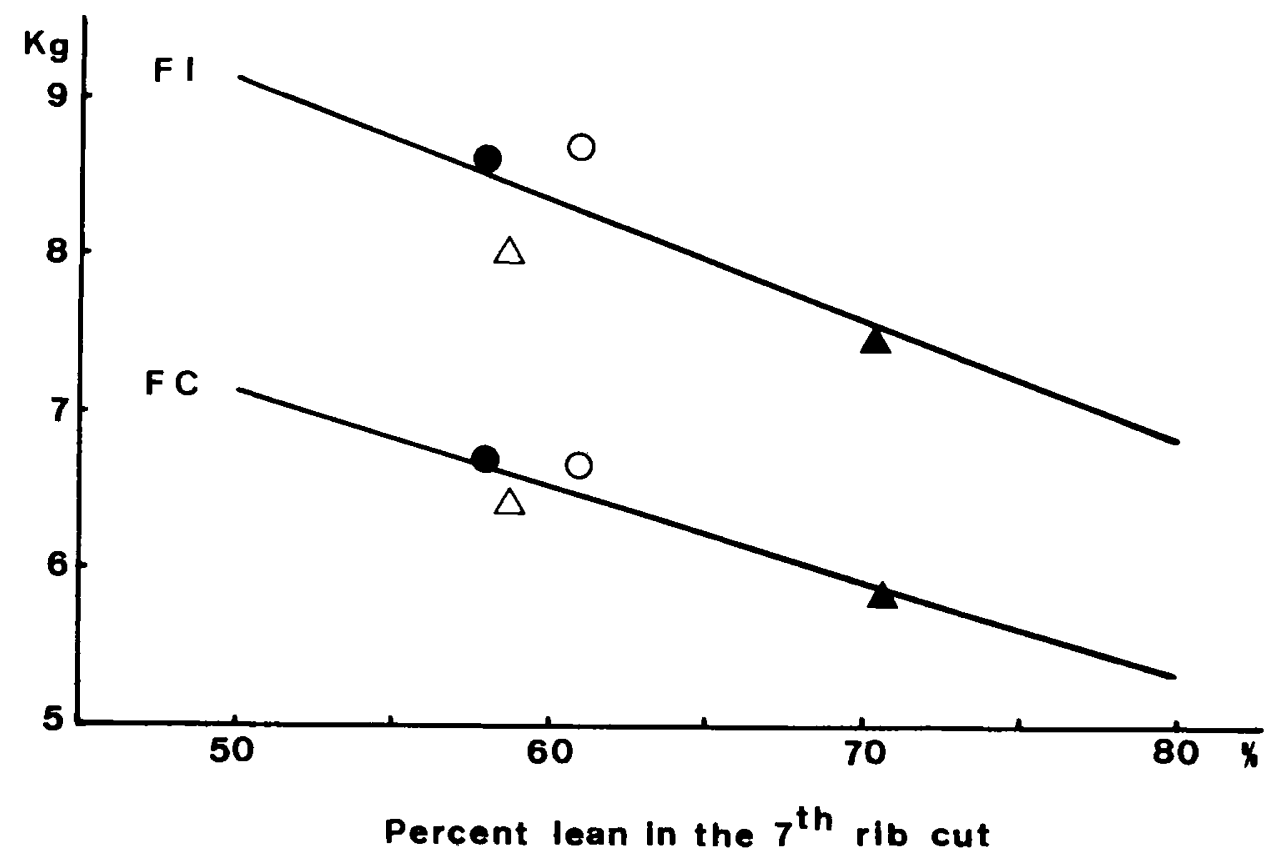

Fig. 3

Regression of feed intake (FI) and of feed conversion (FC) on the percent lean in the $7^{\text {th }}$ ribcut, across biological types. See legend of fig. 2 for the explanation of the symbols.

TABLE 3

Coefficients of determination $\left(R^{2}\right)$ of feed intake by initial weight, daily gain, dressing-out percentage and percent lean.

\begin{tabular}{|c|c|c|c|c|}
\hline Biological type & IW & DG & DO $\%$ & $\%$ LEAN \\
\hline $\begin{array}{l}\text { DM } \ldots \ldots \ldots \\
\text { DM } \times \text { FR. } \ldots \ldots \ldots \\
\text { DM } \times \text { MRY } \ldots \ldots \ldots \\
\text { CONV } \ldots \ldots \ldots \ldots\end{array}$ & $\begin{array}{l}0.3516^{3}(+) \\
0.3469^{3}(+) \\
0.4494^{2}(+) \\
0.2357^{3}(+)\end{array}$ & $\begin{array}{l}0.2858^{3}(+) \\
0.3325^{3}(+) \\
0.1587(+) \\
0.2205^{3}(+)\end{array}$ & $\begin{array}{l}0.0210^{3}(+) \\
0.0046(+) \\
0.0505(+) \\
0.0029(-)\end{array}$ & $\begin{array}{l}0.0168^{2}(-) \\
0.0235(-) \\
0.0410(-) \\
0.0016(-)\end{array}$ \\
\hline & $I W+D G$ & \multicolumn{2}{|c|}{$I W+D G+D O \%$} & IW + DG + \% LEAN \\
\hline $\begin{array}{l}\text { DM } \ldots \ldots \ldots \\
\text { DM } \times \text { FR. } \ldots \ldots \ldots \\
\text { DM } \times \text { MRY } \ldots \ldots \ldots \\
\text { CONV } \quad \ldots \ldots \ldots\end{array}$ & $\begin{array}{l}0.5615^{3} \\
0.5128^{3} \\
0.5704^{3} \\
0.3752^{3}\end{array}$ & \multicolumn{2}{|c|}{$\begin{array}{l}0.5617^{3} \\
0.5220^{3} \\
0.5743^{3} \\
0.3755^{3}\end{array}$} & $\begin{array}{l}0.5641^{3} \\
0.5132^{3} \\
0.6026^{3} \\
0.3753^{3}\end{array}$ \\
\hline
\end{tabular}

IW = initial weight ; DG = daily gain ; DO $\%=$ dressing-out percentage $;$ superscript = level of significance ; $1=\mathrm{P}<0.05,{ }^{2}=\mathrm{P}<0.01,{ }^{3}=\mathrm{P}<0.001$. Between parentheses, the sign of the corresponding simple correlation coefficient. 
TABLE 4

Coefficients of determination $\left(R^{2}\right)$ of feed conversion ratio by initial weight, daily gain, dressing-out percentage and percent lean.

\begin{tabular}{|c|c|c|c|c|c|}
\hline Biological type & IW & DG & \multicolumn{2}{|c|}{ DO \% } & $\%$ LEAN \\
\hline $\begin{array}{l}\text { DM } \ldots \ldots \ldots \\
\text { DM } \times \text { FR. } \ldots \ldots \ldots \\
\text { DM } \times \text { MRY } \ldots \ldots \ldots \\
\text { CONV } \quad \ldots \ldots \ldots \ldots\end{array}$ & $\begin{array}{l}0.1825^{3}(+) \\
0.0289(+) \\
0.2641^{1}(+) \\
0.0300^{1}(+)\end{array}$ & $\begin{array}{l}0.3067^{3}(-) \\
0.3749^{3}(-) \\
0.3465^{2}(-) \\
0.5204^{3}(-)\end{array}$ & \multicolumn{2}{|c|}{$\begin{array}{ll}0.0032 & (+) \\
0.0169 & (-) \\
0.0036 & (+) \\
0.0204^{1} & (+)\end{array}$} & $\begin{array}{ll}0.0141^{2} & (-) \\
0.0127 & (+) \\
0.1330 & (+) \\
0.0000 & (+)\end{array}$ \\
\hline & $I W+D G$ & \multicolumn{2}{|c|}{$\mathrm{IW}+\mathrm{DG}+\mathrm{DO} \%$} & IW & OG $+\%$ LEAN \\
\hline $\begin{array}{l}\text { DM } \ldots \ldots \ldots \\
\text { DM } \times \text { FR. } \ldots \ldots \ldots \\
\text { DM } \times \text { MRY } \ldots \ldots \ldots \\
\text { CONV } \quad \ldots \ldots \ldots \ldots\end{array}$ & $\begin{array}{l}0.5639^{3} \\
0.5272^{3} \\
0.6567^{3} \\
0.6309^{3}\end{array}$ & \multicolumn{2}{|c|}{$\begin{array}{l}0.5646^{3} \\
0.5376^{3} \\
0.6609^{3} \\
0.6314^{3}\end{array}$} & & $\begin{array}{l}0.5671^{3} \\
0.5275^{3} \\
0.6787^{3} \\
0.6310^{3}\end{array}$ \\
\hline
\end{tabular}

IW = initial weight ; DG = daily gain ; DO $\%=$ dressing-out percentage ; superscript = level of significance ; ${ }^{1}=\mathrm{P}<0.05,{ }^{2}=\mathrm{P}<0.01,{ }^{3}=\mathrm{P}<0.001$. Between parentheses, the sign of the corresponding simple correlation coefficient.

A comparison, among biological types, of mean feed intake adjusted for initial weight and daily gain was carried out (table 5). The test of equality of slopes was not significant; the test of zero slope and the test of equality of adjusted means were highly significant. The regression coefficients and their standard errors are also given in table 5. Mean feed intake at zero gain could be computed for each biological type.

TABLE 5

Comparison, among biological types, of mean feed intake adjusted for initial weight and daily gain.

\begin{tabular}{c|c|c|c}
\hline \hline Biological type & $\begin{array}{c}\text { Mean feed intake } \\
\text { adjusted for IW } \\
\text { and DG }\end{array}$ & $\begin{array}{c}\text { Mean feed intake } \\
\text { at zero gain }\end{array}$ & $\begin{array}{c}\text { Maintenance } \\
\text { kcal/kg MW }\end{array}$ \\
\hline $\mathrm{DM} \ldots \ldots \ldots \ldots \ldots$ & $7.520^{\mathrm{a}}$ & 4.528 & 131 \\
$\mathrm{DM} \times \mathrm{FR} \ldots \ldots \ldots$ & $8.571^{\mathrm{c}}$ & 5.579 & 161 \\
$\mathrm{DM} \times \mathrm{MRY} \ldots \ldots \ldots$ & $8.581^{\mathrm{c}}$ & 5.589 & 161 \\
CONV. $\ldots \ldots \ldots$ & $7.917^{\mathrm{b}}$ & 4.924 & 142 \\
\hline
\end{tabular}

IW = initial weight $; \mathrm{DG}=$ daily gain $; \mathrm{kg} \mathrm{MW}=\mathrm{kg}$ metabolic weight, $\mathrm{W}^{0.75}$.

Test of equality of adjusted means $P<0.0001$

$$
\begin{array}{ll}
\text { zero slope } & \mathbf{P}<0.0001 \\
\text { equality of slopes } & \mathrm{P}=\mathbf{0 . 4 9 7 3}
\end{array}
$$

Partial regression coefficients of feed intake on :

$$
\begin{array}{ll}
\text { initial weight } & =0.01259 \mathrm{~kg} / \mathrm{kg} \text { (St. er. }=0.00058) \\
\text { daily gain } & =2.33214 \mathrm{~kg} / \mathrm{kg} \text { (St. er. }=0.11521)
\end{array}
$$

mean initial weight $=276.97 \mathrm{~kg}$; mean daily gain $=1.283 \mathrm{~kg}$.

Means with the same letter are not significantly different. 
These values were arrived at through the subtraction, from the adjusted means, of the product of the partial regression coefficient of feed intake on daily gain by the mean gain. These means are given table $5,\left(2^{\text {nd }}\right.$ column $)$ and the corresponding maintenance needs $\left(3^{d}\right.$ column) in $\mathrm{kcal}$ ME per $\mathrm{kg}$ metabolic weight (midweight ${ }^{0.75}=376^{0.75}$, the concentrate having a dry matter content of $88 \%$ and the energy content of $1 \mathrm{~kg}$ dry matter being $2800 \mathrm{kcal} \mathrm{ME}$ ).

These estimates of maintenance requirements are very rough and larger than those reported from nutrition experiments (see FERRELL \& JENKINS, 1985 for a review of these estimates).

Nevertheless, this analysis strongly suggests that differences exist among biological types regarding their maintenance needs and in particular between double-muscled and conventional bulls, both types having been tested in the same years. On the other hand, there were no difference among biological types regarding the growth requirement.

TABLE 6

Annual variations of the selling price per kilo liveweight and of the net income for each biological type.

\begin{tabular}{|c|c|c|c|c|c|c|}
\hline $\begin{array}{l}\text { Biological type } \\
\text { (year) }\end{array}$ & $\mathbf{n}$ & SP & $\mathbf{s}$ & NI & $\mathbf{s}$ & $\begin{array}{l}\text { Feed costs } \\
\text { Price } / k g \\
\text { concentrate }\end{array}$ \\
\hline \multicolumn{7}{|l|}{$D M$} \\
\hline$\ldots \ldots \ldots$ & 57 & 104.60 & 7.92 & 69.50 & 22.20 & 8 \\
\hline$\ldots \ldots \ldots \ldots$ & 62 & 108.60 & 6.07 & 80.73 & 16.41 & 8 \\
\hline$\ldots \ldots \ldots$ & 85 & 106.62 & 7.01 & 69.33 & 17.66 & 8 \\
\hline 1981 & 123 & 103.00 & 7.58 & 79.79 & 20.10 & 8 \\
\hline 1982 & 128 & 115.10 & 6.69 & 73.92 & 18.81 & 10 \\
\hline 1983 & 78 & 126.65 & 7.59 & 86.35 & 22.73 & 10 \\
\hline $1984 \ldots$ & 92 & 131.20 & 6.80 & 76.70 & 22.60 & 12.8 \\
\hline \multicolumn{7}{|l|}{$D M \times F R$} \\
\hline $1981 \ldots$ & 21 & 70.09 & 2.62 & 23.05 & 7.41 & 8 \\
\hline $1985 \ldots$ & 73 & 87.10 & 3.30 & 17.33 & 10.50 & 11.3 \\
\hline \multicolumn{7}{|l|}{$D M \times M R Y$} \\
\hline $1985 \ldots$ & 20 & 89.20 & 2.90 & 18.96 & 10.00 & 11.3 \\
\hline \multicolumn{7}{|l|}{ CONV. } \\
\hline 1978 & 71 & 67.10 & 3.31 & 19.66 & 11.67 & 8 \\
\hline 1979 & 83 & 67.18 & 3.57 & 23.64 & 11.53 & 8 \\
\hline 1980 & 31 & 67.84 & 2.76 & 21.31 & 10.96 & 8 \\
\hline
\end{tabular}

$\mathrm{SP}=$ selling price $; \mathrm{NI}=$ net income $; \mathrm{s}=$ standard deviation $; \mathrm{n}=$ sample size. 


\section{B. Economic traits}

The yearly variations of the selling price per kilo liveweight and of the net income are given, separately for each biological type, in table 6. Once more, the differences between the double-muscled type, on the one hand, and the other types on the other hand, are quite striking. For the year 1980, the selling price of the double-muscled exceeded that of the conventional by 57 p. 100 while, at the same time, the net income was 3.25 times higher.

The relations between the selling price and objective measurements were investigated within years. The results of this analysis are presented in table 7 . The traits considered were : final weight, dressing-out percentage, percent lean in the $7^{\text {th }}$ ribcut. Final weight and dressing-out percentage explained a significant part of the variation of the selling price. When all 3 traits were considered, $25 \mathrm{p} .100$ of the variation of the selling price is accounted for in the double-muscled animals, 40 p. 100 in the conventional (CONV) and the DM $\times$ FR crossbred animals.

TABLE 7

Coefficients of determination $\left(R^{2}\right)$ of selling price per kilo liveweight by final weight, dressing-out percentage and percent lean in the 7 th ribcut.

\begin{tabular}{|c|c|c|c|}
\hline Biological type & FW & DO $\%$ & $\%$ LEAN \\
\hline \multirow[t]{2}{*}{$\begin{array}{l}\text { DM } \ldots \ldots \ldots \\
\text { DM } \times \text { FR. } \ldots \ldots \\
\text { DM } \times \text { MRY } \ldots \ldots \\
\text { CONV } \ldots \ldots \ldots\end{array}$} & $\begin{array}{l}0.1312^{3}(+) \\
0.2138^{3}(+) \\
0.3042^{1}(+) \\
0.1863^{3}(+)\end{array}$ & $\begin{array}{l}0.1226^{3}(+) \\
0.2394^{3}(+) \\
0.4570^{2}(+) \\
0.2021^{3}(+)\end{array}$ & $\begin{array}{l}0.0386^{3}(+) \\
0.0263(+) \\
0.0367(+) \\
0.0995^{3}(+)\end{array}$ \\
\hline & FW + DO \% & $\mathrm{FW}+\%$ LEAN & FW + DO $\%+\%$ LEAN \\
\hline $\begin{array}{l}\text { DM } \ldots \ldots \ldots \\
\text { DM } \times \text { FR. } \ldots \ldots \\
\text { DM } \times \text { MRY } \ldots \ldots \\
\text { CONV } \ldots \ldots \ldots \ldots\end{array}$ & $\begin{array}{l}0.2157^{3} \\
0.3696^{3} \\
0.5652^{3} \\
0.3659^{3}\end{array}$ & $\begin{array}{l}0.1880^{3} \\
0.2768^{3} \\
0.5858^{3} \\
0.3018^{3}\end{array}$ & $\begin{array}{l}0.2473^{3} \\
0.4043^{3} \\
0.7290^{3} \\
0.4177^{3}\end{array}$ \\
\hline
\end{tabular}

FW $=$ final weight $; \mathrm{DO} \%=$ dressing-out percentage $;$ superscript $=$ level of significance ${ }^{1}=\mathrm{P}<0.05$, ${ }^{2}=\mathrm{P}<0.01,{ }^{3}=\mathrm{P}<0.001$. Between parentheses, the sign of the corresponding simple correlation coefficient.

The contribution made to the variation of net income by the following traits : initial weight, daily gain, feed intake, feed conversion and selling price have been estimated, within years for the 4 biological types (table 8).

As single traits, daily gain and feed conversion ratio are most closely related to net income. They are followed by selling price.

High coefficients of determination are obtained when 2 or 3 traits are included in the multiple regression equations, even if feed intake and feed conversion are not 
TABLE 8

Coefficients of determination $\left(R^{2}\right)$ of net income by initial weight, daily gain, feed intake, feed conversion ratio and selling price.

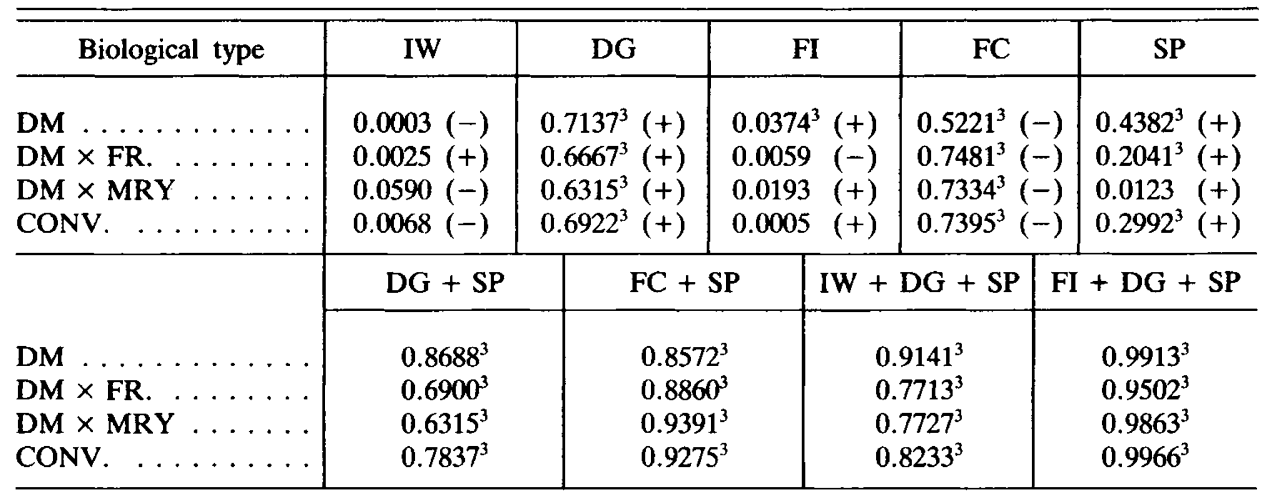

IW = initial weight $;$ DG = daily gain $; \mathrm{FI}=$ feed intake $; \mathrm{FC}=$ feed conversion ratio $; \mathrm{SP}=$ selling price $;$ supers. cript $=$ level significance $;^{3}=\mathrm{P}<0.05,,^{2}=\mathrm{P}<0.01,{ }^{3}=\mathrm{P}<0.001$. Between parentheses, the sign of the corresponding simple correlation coefficient.

known $(\mathrm{DG}+\mathrm{SP}$ and $\mathrm{IW}+\mathrm{DG}+\mathrm{SP})$. Due to the way net income was computed, complete determination was as expected achieved when feed intake, daily gain and selling price were considered together.

\section{Genetic parameters}

In this experiment, feed intake per unit gain is evaluated over a time-constant interval and it seemed reasonable to adjust the data for differences in maintenance requirements. Three variables were therefore derived:

1) the ratio of weight gain (final weight minus initial weight) : lighter-than-average bulls are adjusted upwards and heavier-than-average bulls downwards, this ratio could be used as an indirect measure of feed conversion when feed intake is not recorded ;

2) the adjusted feed consumption : feed intake is adjusted for daily gain and midweight on the basis of the following regression equation drawn from our data (double-muscled animals) : food consumption $=0.82+1.46$ (daily gain) +0.013 (midweight). It has been suggested that this criterion could be a measure of "intrinsic " feed efficiency (КосH et al., 1963) but this correction does not take into account the effect of the composition of gain on the efficiency (DicKerson, 1982) ;

3) the adjusted feed conversion ratio : the feed conversion ratio is multiplied by the ratio of test group average metabolic midweight to the individual's own metabolic midweight (W.75) (B.I.F., 1981; DAvis et al., 1985) ; heavier-than-average bulls are adjusted downwards and lighter-than-average bulls upwards.

Genetic parameters (heritabilities and genetic correlations) were estimated « within the double-muscled type". The estimates and their standard errors and the "within years " standard deviation of each trait are given in table 9. Daily gain, ratio of gain to 
initial weight, feed conversion, net income, dressing-out percentage and percent lean had a coefficient of heritability of about 0.4 or greater. The estimate of heritability of final weight was 0.2 : this is lower than most estimates (but not all) that have been reported for this trait (Preston \& Willis, 1974, p. 105-119). VAlls-OrTIZ et al. (1972) found distinctly lower heritabilities for double-muscled sires as compared to normal sires, the traits considered being 60 day weight and beef type score. This observation should not be generalized since, in our data, daily gain, for instance, had an heritability of 0.44 , quite similar to 0.41 , the average of 354 literature estimates, computed by Simm et al. (1986).

The adjusted variables had a reduced heritability compared with their unadjusted forms. By the adjustment of food consumption, the genetic standard deviation drops from $0.44 \mathrm{~kg}$ to $0.25 \mathrm{~kg}$ thus leaving little scope for selection.

The genetic correlations had in general a high standard error. In the interpretation of the coefficients of correlation, one has to bear in mind that often a portion of the relationship is automatic (a part and its whole; a variable and a ratio with the same variable as numerator or denominator).

Initial weight was highly correlated with final weight, ratio of gain to initial weight (automatic), food intake in the subsequent period, feed conversion. The effect of initial weight was much greater on feed intake and feed conversion than on gain. All other things being equal, a higher initial weight means higher maintenance costs through the whole fattening period. The correlation between initial weight and gain was slight (phenotypic) and even negative (genetic) but the environmental correlation was positive $(+0.380)$. This observation was confirmed on independent and unpublished data collected in the same Testing Station, the phenotypic, genetic and environmental correlations being respectively : $+0.139,-0.091$ (s.e. $=0.349$ ) and +0.188 (number of offspring : 822 ; number of sires : 56 ).

Final weight was correlated with gain, adjusted feed intake, net income, and there was a slight tendency for the heavier individuals to have a higher dressing-out percentage and to be fatter.

Final weight was not correlated with adjusted food consumption and feed conversion. Final weight consist of 2 components : initial weight and gain which had opposite effects on feed conversion.

Daily gain was highly correlated with net income and, as expected, more closely related to adjusted feed conversion than to unadjusted feed conversion.

The ratio of gain to initial weight was highly correlated with feed conversion (phenotypic and genetic), and with net income (genetic).

Adjusted feed consumption was more highly correlated with feed conversion than unadjusted feed consumption.

Feed conversion was highly correlated with adjusted feed conversion and net income and there was a tendency for the leaner individual to be more efficient. Adjusted feed conversion was closely related to net income.

Net income was phenotypically correlated with (in decreasing order of importance) : daily gain (0.85), adjusted feed conversion $(-0.83)$, feed conversion $(-0.73)$, ratio of gain to initial weight $(0.63)$, final weight $(.45)$, percent lean $(0.165)$ and dressing-out percentage $(0.16)$. 


\begin{tabular}{|c|c|c|c|c|c|c|c|c|c|c|c|c|c|}
\hline & $\frac{\tilde{N}}{\stackrel{2}{0}}$ & $\begin{array}{l}\overrightarrow{5} \\
\stackrel{0}{0} \\
1\end{array}$ & $\stackrel{\nabla}{\Delta}$ & $\frac{\overline{8}}{\frac{1}{0}}$ & $\frac{\tilde{Z}}{0}$ & $\begin{array}{l}\bar{n} \\
\frac{1}{0} \\
1\end{array}$ & $\begin{array}{l}\tilde{\tilde{N}} \\
\stackrel{0}{0} \\
1\end{array}$ & $\begin{array}{l}\widetilde{\delta} \\
0 \\
0 \\
1\end{array}$ & $\frac{n}{8}$ & 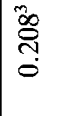 & $\begin{array}{l}30 \\
8 \\
0 \\
0 \\
0\end{array}$ & 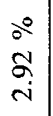 & \\
\hline 은 & $\frac{3}{3}$ & $\frac{n}{5}$ & 帒 & $\begin{array}{l}\bar{g} \\
\text { oे } \\
0 \\
1\end{array}$ & $\vec{z}$ & $\begin{array}{l}\widetilde{1} \\
0 \\
0 \\
1\end{array}$ & గ్రి & $\begin{array}{l}0 \\
0 \\
0 \\
1 \\
1\end{array}$ & $\begin{array}{l}3 \\
\stackrel{0}{0} \\
0\end{array}$ & $\begin{array}{l}0 \\
\hat{n} \\
0 \\
0 \\
0\end{array}$ & 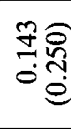 & $\frac{0}{n}$ & \\
\hline$a$ & $\begin{array}{l}\stackrel{8}{\circ} \\
\stackrel{0}{0} \\
1\end{array}$ & $\stackrel{m}{\vec{n}}$ & $\begin{array}{l}m \\
\overrightarrow{0} \\
\infty \\
0\end{array}$ & $\begin{array}{l}\stackrel{m}{\Delta} \\
\stackrel{\delta}{0} \\
\stackrel{0}{0}\end{array}$ & ్ֻ̊ㅇ & 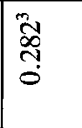 & $\begin{array}{l}\stackrel{3}{5} \\
\vdots \\
1\end{array}$ & $\begin{array}{l}\tilde{N} \\
\infty \\
0 \\
0 \\
1\end{array}$ & 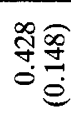 & 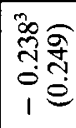 & 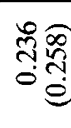 & $\begin{array}{l}\frac{1}{\infty} \\
\frac{1}{\grave{d}}\end{array}$ & \\
\hline$\infty$ & $\begin{array}{l}0 \\
0 \\
0 \\
0 \\
1\end{array}$ & $\begin{array}{l}\tilde{a} \\
\hat{n} \\
0 \\
1\end{array}$ & 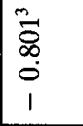 & $\begin{array}{l}\stackrel{\tilde{J}}{\tilde{\gamma}} \\
\dot{0} \\
1\end{array}$ & $\begin{array}{l}\overline{8} \\
\stackrel{0}{0} \\
1 \\
1\end{array}$ & 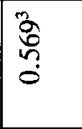 & $\begin{array}{l}30 \\
\frac{3}{2} \\
0\end{array}$ & 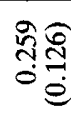 & 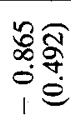 & 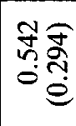 & $\begin{array}{l}\frac{9}{9} \frac{n}{0} \\
\text { ie }\end{array}$ & $\begin{array}{l}\frac{80}{y} \\
\stackrel{n}{\circ} \\
\vdots \\
0\end{array}$ & \\
\hline$r$ & 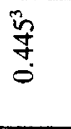 & $\stackrel{0}{0}$ & $\begin{array}{l}n \\
0 \\
n \\
0 \\
1\end{array}$ & $\underset{0}{\stackrel{2}{2}}$ & 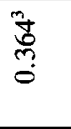 & $\begin{array}{l}\hat{\tilde{C}} \\
\text { ర్ర } \\
0\end{array}$ & 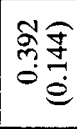 & 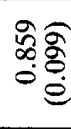 & 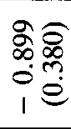 & 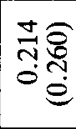 & 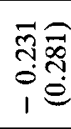 & 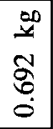 & \\
\hline 0 & $\stackrel{\mathbb{Z}}{0}$ & $\stackrel{\square}{0}$ & $\begin{array}{l}\hat{8} \\
0 \\
1\end{array}$ & $\stackrel{a}{0}$ & 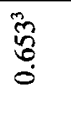 & 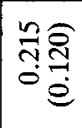 & 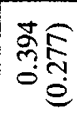 & 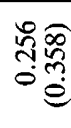 & 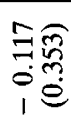 & 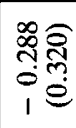 & సે & $\begin{array}{l}\stackrel{0}{0} \\
\stackrel{n}{n} \\
\tilde{n} \\
0\end{array}$ & $\dot{8}$ \\
\hline in & 萬 & $\frac{3}{8}$ & \begin{tabular}{l}
$\infty$ \\
\multirow{n}{n}{} \\
0 \\
0
\end{tabular} & $\begin{array}{l}\mathscr{2} \\
0 \\
0 \\
1\end{array}$ & 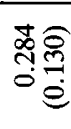 & $\begin{array}{l}\stackrel{0}{0} \supseteqq \\
\stackrel{0}{0}\end{array}$ & 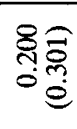 & 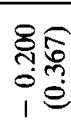 & 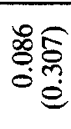 & 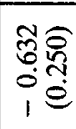 & సٓ월 & $\begin{array}{l}\infty \\
\stackrel{x}{2} \\
\approx \\
\infty \\
0 \\
0\end{array}$ & $\begin{array}{l}0 \\
V \\
2 \\
11 \\
m\end{array}$ \\
\hline$\nabla$ & \begin{tabular}{l}
$\tilde{n}$ \\
\multirow{0}{0}{} \\
0 \\
1
\end{tabular} & $\frac{\tilde{\tilde{m}}}{\stackrel{0}{0}}$ & 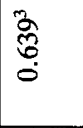 & 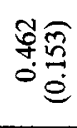 & $\begin{array}{l}\infty \widehat{0} \\
\stackrel{0}{0} \\
0\end{array}$ & 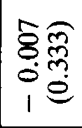 & 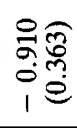 & 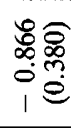 & รั5 & 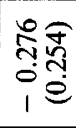 & 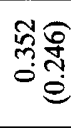 & $\begin{array}{l}0 \\
0 \\
\dot{m} \\
\dot{q}\end{array}$ & $\begin{array}{l}\overrightarrow{0} \\
0 \\
V \\
V \\
0\end{array}$ \\
\hline$m$ & $\frac{\widetilde{N}}{\sigma}$ & $\begin{array}{l}\frac{m}{7} \\
\stackrel{0}{0} \\
0\end{array}$ & $\frac{\forall}{\frac{+}{2}}$ & $\begin{array}{l}\hat{\sigma} \mathscr{8} \\
\text { ᄋ̊ }\end{array}$ & 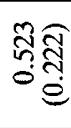 & 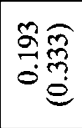 & 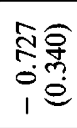 & 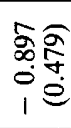 & 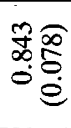 & 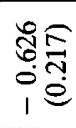 & 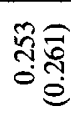 & $\begin{array}{l}\frac{20}{20} \\
8 \\
8 \\
0 \\
0\end{array}$ & $\begin{array}{l}n \\
\ddot{0} \\
\ddot{0} \\
0 \\
v\end{array}$ \\
\hline$N$ & $\begin{array}{l}\frac{m}{\infty} \\
\infty \\
0\end{array}$ & స్융 & 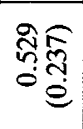 & 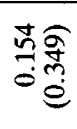 & 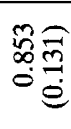 & 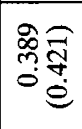 & 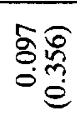 & \begin{tabular}{l}
$\infty$ \\
$\forall$ \\
\hdashline \\
0 \\
$i$
\end{tabular} & 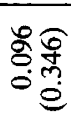 & 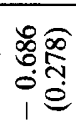 & 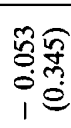 & $\begin{array}{l}00 \\
\dot{y} \\
\dot{0} \\
\dot{J}\end{array}$ & $\begin{array}{l}0 \\
11 \\
\ddot{\ddot{z}} \\
\ddot{\ddot{z}}\end{array}$ \\
\hline- & ণึণ & 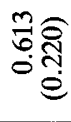 & 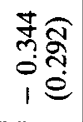 & 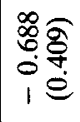 & 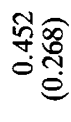 & 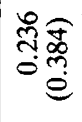 & 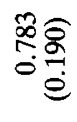 & 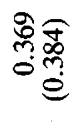 & 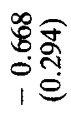 & 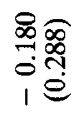 & 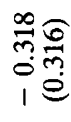 & $\begin{array}{l}\infty 0 \\
\dot{x} \\
\infty \\
\infty \\
m\end{array}$ & 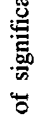 \\
\hline & 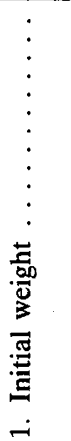 & 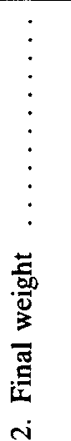 & 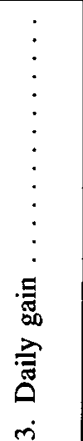 & 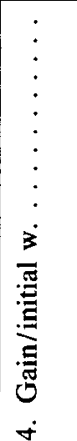 & 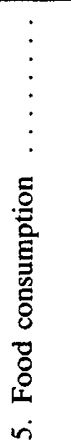 & 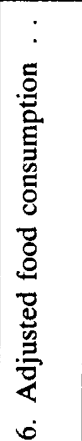 & 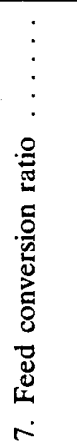 & 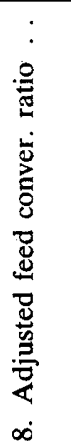 & 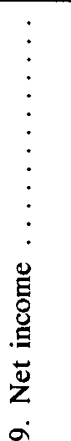 & 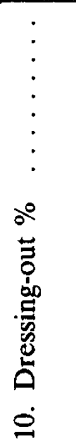 & 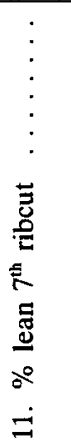 & 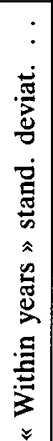 & 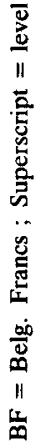 \\
\hline
\end{tabular}




\section{Discussion}

Regarding feed conversion ratio and carcass composition, the double-muscled type is quite distinct from the other types. It was already the case when the same biological types were characterized by the blood levels of creatine and creatinine (HANSET \& MichaUX, 1986).

Feed efficiency is favourably influenced by :

1) a higher energy digestibility/metabolisability ;

2) a high daily gain relative to mean weight ;

3) a leaner gain ;

4) a lower maintenance requirement per $\mathrm{kg}$ metabolic weight ;

5) a lower requirement in metabolizable energy per $g$ of lipids or proteins laid down.

The higher feed efficiency of the double-muscled animal, which is a well-established fact, could be due either to its body gain composition or to lower maintenance requirements or to both (HANSET et al., 1979). GEAY et al. (1982) have also considered the possibility of lower maintenance requirements in double-muscled animals. The reasons put forward by these authors are : 1) lower activity ; 2) slower protein turnover due to a less developed digestive tract and to a higher proportion of white fibers. The present data indicate that the double-muscled bull has a lower maintenance requirement. Nevertheless, the general concept is that $\mathrm{ME}$ requirement for maintenance tends to be lower per unit metabolic weight in fat animals than in lean animals (Dickerson, 1985 ; Webster, 1985). However, data reviewed by FerRell \& Jenkins (1985) shed doubt on the relationships : 1) between body composition per se and maintenance energy expenditures ; 2) between composition of gain and energetic efficiency. On the contrary, metabolism of visceral organs constitutes a major proportion of total animal energy expenditures. Variation in energy expenditures among breeds, among individuals within breeds, could be attributable to variation in metabolism of visceral organs. VERMOREL et al. (1976) found that minimum heat production (fasting metabolism) was 12 p. 100 lower in Charolais than in Friesian bulls. For WeBSTER (1985), this result «suggests that the Charolais does share to a degree with the Hereford the useful beefy trait of a low metabolic heat production ». Increased muscle relative to visceral development would reduce metabolic heat loss from non fat tissue activity (DICKERSON, 1985).

Lower maintenance requirement not associated with reduced growth potential, or adult size or milking potential is also expected in the adult double-muscled animal but until now, no data were available. Now, maintenance requirement is a major proportion of total feed cost in animal production (DiCKERSON, 1982, 1985) and a decrease in the maintenance cost of the mature animal is considered by THOMPSON \& BARLow (1986) as a promising avenue for increasing biological efficiency of the total production system. An increase in lean content is associated not only with higher feed conversion but also with a higher market value of the young and of the cull cow (Dickerson, 1982). This is particularly true in the Belgian Blue breed where an improvement of the lean content of the whole carcass from 65 p. 100 to 78 p. 100 (Michaux et al., 1983) has been achieved not gradually as in the case of polygenic inheritance but rather quickly thanks to the fixation of the partially recessive gene for muscle hypertrophy 
(Hanset, 1982 ; Hanset \& Michaux, 1985a, 1985b). The better selling price per $\mathrm{kg}$ liveweight due to muscle hypertrophy $(+40 \mathrm{BF})$ was the main incentive for this selection and the better feed conversion $(-0.52 \mathrm{~kg})$ should be considered as a bonus. Of the difference in net income between double-muscled and conventional or crossbreed which amounts to $57.876 \mathrm{BF}$ (daily gain : $1.3 \mathrm{~kg}$; feed cost : $11.3 \mathrm{BF} / \mathrm{kg}$ ), only $5.876 \mathrm{BF}$ or 10 p. 100 is due to the better feed conversion.

Within the double-muscled type, the prospects of genetic improvement in feed efficiency through higher daily gain relative to weight look better than through other means such as composition or above-maintenance feed energy cost of protein and fat deposition.

On the basis of the estimates of the genetic parameters presented in table 9 , it was possible to evaluate the consequences of selections on : 1) daily gain ;2) ratio of gain to initial weight ; 3) feed conversion ; 4) adjusted feed conversion ; 5) net income as defined above ; 6) final weight ; 7) index I where the traits included in the aggregate genotype and in the index were : daily gain and food intake and the economic weights used were : 130 (value of one $\mathrm{kg}$ liveweight) and -11.3 (cost of one $\mathrm{kg}$ concentrate) respectively ; the coefficients of the index were : 60.23 and $-4.8, \mathrm{R}_{\mathrm{HI}}=0.68 ; 8$ ) index II where the aggregate genotype was the same as in 7) above but the traits included in the index (the measured traits) were : daily gain and initial weight ; the coefficients of the index were : 50.46 and -0.138 with $\mathrm{R}_{\mathrm{HI}}=0.74$.

The expected genetic superiority in the selected trait and the expected correlated response in the other traits are given in table 10 for a selection differential equal to $i=+1$ for all traits considered except for feed efficiency $(i=-1)$. These results should be interpreted cautiously because of large standard errors of estimates.

Daily gain was improved in all instances, but least in the case of selection on final weight. Feed conversion was bettered in all cases except when final weight was the selection criterion.

With the exception of final weight as selection criterion, all the other criteria gave a similar picture : daily gain, feed conversion ratio and net income were improved, initial weight was lowered. Final weight was increased the most when selecting on daily gain or on final weight; it was even slightly reduced when selecting on feed conversion. Feed intake increased the most when selecting on daily gain or on final weight. A higher efficiency and a greater income were associated with lower maintenance requirements. It would seem that net income can be substantially improved in the absence of food intake recording.

In most cases reported in the literature, genetic improvement in feed conversion has been obtained as a correlated response to selection for increased liveweight gain rather than by direct selection. Nevertheless, considering that « for all practical purposes, feed conversion can be considered the most important parameter in any feedlot operation », Preston \& Willis (1974, pp. 441-444) advocate a selection of sires on feed conversion ratio after a performance test starting at some 90 days of age and ending at a fixed weight. Selection on feed conversion is not as closely associated with large size as is selection on daily gain or on final weight. Although feed conversion is a combination of the 2 traits : gain and food consumption, selection for feed conversion does not give the highest return because its 2 component characters are not properly weighted as they appear to be in the case of "net income ». In the case of index I, the weight are correct provided we have prior knowledge of the genetic parameters. 


\section{TABLE 10}

Direct and correlated responses in the case of selection for 1) daily gain ; 2) ratio of gain to initial weight ; 3) feed conversion ratio ; 4) adjusted feed conversion ; 5) net income ; 6) final weight ;

7) index $I ; 8$ ) index II.

Direct or correlated response in :

\begin{tabular}{|c|c|c|c|c|c|c|}
\hline $\begin{array}{l}\text { Selection } \\
\text { criterion }\end{array}$ & $\begin{array}{l}\text { Daily } \\
\text { gain } \\
(\mathbf{k g})\end{array}$ & 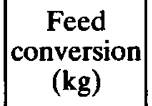 & $\begin{array}{c}\text { Net } \\
\text { income } \\
\text { (B.F.) }\end{array}$ & $\begin{array}{c}\text { Initial } \\
\text { weight } \\
\text { (kg) }\end{array}$ & $\begin{array}{c}\text { Feed } \\
\text { intake } \\
(\mathrm{kg})\end{array}$ & $\begin{array}{c}\text { Final } \\
\text { weight } \\
\text { (kg) }\end{array}$ \\
\hline Daily gain & +0.071 & -0.210 & +7.46 & -4.07 & +0.154 & +7.04 \\
\hline $\begin{array}{l}\text { Ratio of gain to initial } \\
\text { weight } \ldots \ldots \ldots \ldots\end{array}$ & +0.067 & -0.269 & +8.99 & -8.29 & +0.057 & +2.10 \\
\hline Feed conversion ratio & +0.048 & -0.271 & +7.45 & -8.68 & -0.055 & -1.20 \\
\hline Adjusted feed conversion & +0.049 & -0.189 & +5.82 & -3.32 & +0.045 & +4.26 \\
\hline Net income $\ldots \ldots \ldots \ldots$ & +0.059 & -0.255 & +8.69 & -7.76 & +0.025 & +1.26 \\
\hline Final weight & +0.025 & +0.019 & +0.57 & +4.88 & +0.169 & +8.99 \\
\hline Index I $\ldots \ldots \ldots$ & +0.069 & -0.269 & +8.45 & -6.84 & +0.067 & +3.89 \\
\hline Index II & +0.076 & -0.287 & +9.28 & -8.63 & +0.086 & +3.09 \\
\hline
\end{tabular}

Index $I$ = aggregate genotype : daily gain and feed intake ; measured traits : daily gain and feed intake. Index II = aggregate genotype : as index I ; measured traits : daily gain and initial weight.

The ratio of weight gain to initial weight appeared to be a good selection criterion to increase net income thanks to its high genetic correlation with the latter. The same was the case for index II which is made up of the 2 traits gain and initial weight but for its construction genetic parameters need to be known. Nevertheless, food intake recording offers the possibility of exploiting any genetic difference regarding "intrinsic " food conversion independent of body composition.

Another way of considering the consequences of selection is to compare the performance characteristics of the four best and the four worst bulls for each selection criterion. These comparisons have been made on the same material as above and the results are presented in table 11 . These figures have the meaning of phenotypic superiorities.

Next to direct selection on net income, selection for daily gain and adjusted feed conversion gave the best return. The ratio of gain to initial weight gave the lowest return because very light bulls were selected, with, and as a consequence, a low selling price. The best bulls had a lower initial weight if identified by net income, ratio of gain to initial weight or feed conversion. Davis et al. (1985) also found that the bulls with the lowest ratio of feed to gain were lighter at the start of the postweaning performance test.

The difference for final weight was larger if the bulls were identified by their adjusted feed conversion rather than by their unadjusted feed conversion as also shown by Davis et al. (1985). 


\begin{tabular}{|c|c|c|c|c|c|c|c|}
\hline$\frac{5}{\tilde{E}}$ & 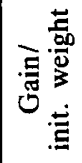 & 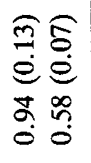 & 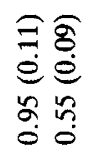 & 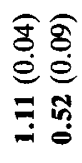 & 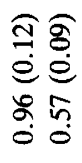 & 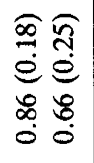 & 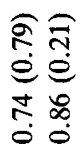 \\
\hline $\begin{array}{l}\frac{5}{5} \\
\frac{5}{0} \\
5 \\
5\end{array}$ & 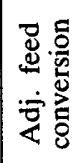 & 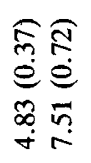 & 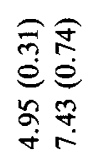 & 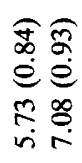 & 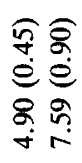 & 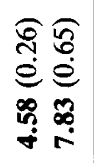 & 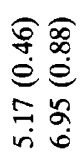 \\
\hline 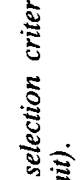 & 矛泀 & 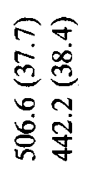 & 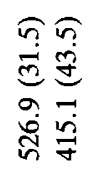 & 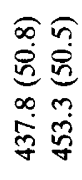 & 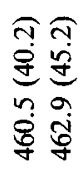 & 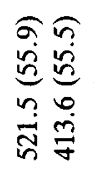 & 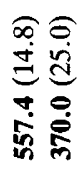 \\
\hline 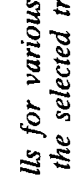 & 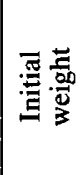 & 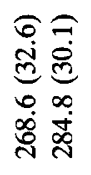 & 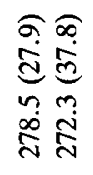 & 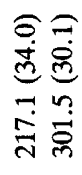 & 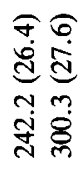 & 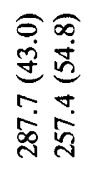 & 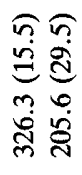 \\
\hline 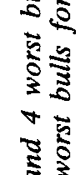 & 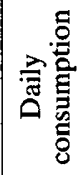 & 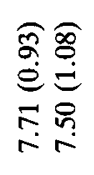 & 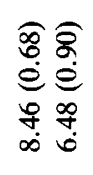 & 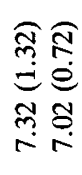 & 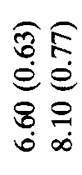 & 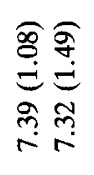 & 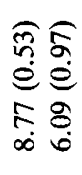 \\
\hline 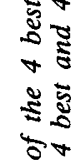 & 育·喅 & 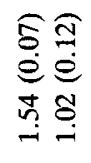 & 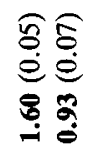 & 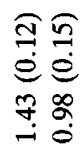 & 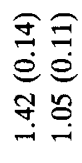 & 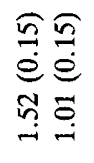 & 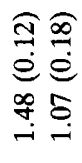 \\
\hline 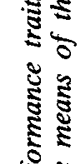 & 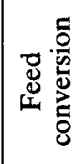 & 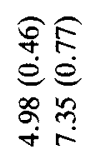 & 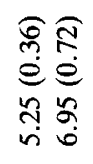 & 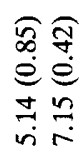 & 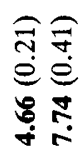 & 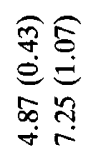 & 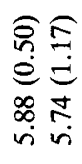 \\
\hline 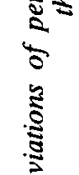 & 己苛 & 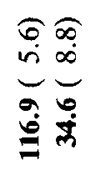 & 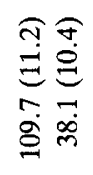 & 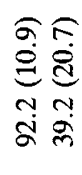 & 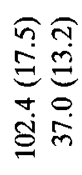 & 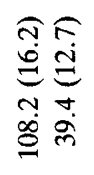 & 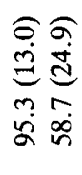 \\
\hline 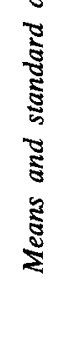 & 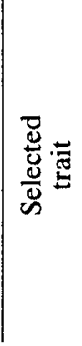 & 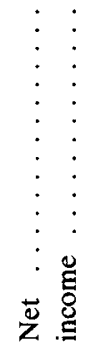 & 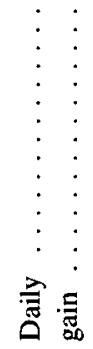 & 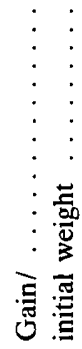 & 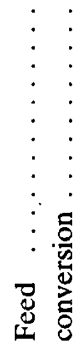 & 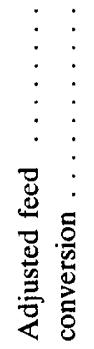 & 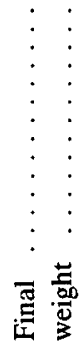 \\
\hline
\end{tabular}


The final weight of the best bulls was lowest if selection was based on the ratio of gain to initial weight or on unadjusted feed conversion ratio.

The bulls selected for the best net income were lighter in final weight than those selected on daily gain or on adjusted feed conversion. The results of table 11 are similar to those of table 10 except for the ratio of gain to initial weight which became a poor selection criterion. In the variation of net income this ratio accounts for 37.65 p. 100 while daily gain accounts for 71.37 p. 100 as shown in table 8 .

Feed conversion is known to differ depending on whether measurement is over a « constant age » interval, a « weight constant » interval or a « fixed age - fixed weight » interval as discussed by SMiтh et al. (1976), CUNDIFF et al. (1981), Косн et al. (1982b), Pym (1982), RoberTson (1982). In pig breeding, feed conversion is generally evaluated over " weight constant » intervals. In cattle, the 3 systems are used. Over time-constant intervals, faster growing animals are either penalized or the opposite depending on the weight they maintain. For this reason it has been recommended that the feed conversion ratio is adjusted for differences in maintenance requirements if bulls are to be evaluated for efficiency of gain (BIF, 1981).

A high growth rate during the testing period will usually mean a high growth rate also at later stages in animals retained for breeding. The result will be in some increase of adult size with the following consequences : a higher value of the cull cow but higher maintenance requirements unless a " bending " of the growth curve can be achieved as discussed by Frtzhugh (1976), Robertson (1982), Grossman \& Bohren (1985), ThompSON \& BARLOW (1986).

Until now, environmental manipulations have been more successful than genetic selection in altering the shape of the growth curve either by restricted feeding during early stages of growth followed by compensatory growth on a high energy diet or through the administration of growth promoting agents near the end of the finishing period providing, in each case, a high daily gain relative to mean weight.

A genetic bending of the growth curve will be possible if genetic correlations for growth at different ages permit. Repeatability of gain in successive periods may be low or even negative as periodic gains tend to be cyclic and compensatorial (CARTWRIGHT \& Dayhoff, 1959 ; Preston \& Willis, 1974).

Both linear and quadratic partial regression coefficients for on-test ADG on initial weight were found to be significant by Tong (1982) and by Brown et al. (1986). The positive regression of on-test ADG on initial weight for a given age is considered by ToNG (1982) as « a consequence of high genetic correlations for growth at different ages ». Nevertheless, the phenotypic correlations between pretest daily gain and on-test daily gain were low, ranging from 0.02 to -0.15 (Tong, 1982).

SWIGER (1961) estimated the genetic parameters of gain in each five 28-day periods after weaning. Heritability was highest for the second period $(0.28)$ and decreased for successive periods, being equal to 0.04 for the fifth period gain. The phenotypic correlations between periodic gains were low (from -0.01 to 0.19 ) but the genetic correlations were large (from 0.19 to 0.88 ) and tended to be higher between gains made in adjacent time periods. This suggests that most of the genes influencing growth in different periods are the same. The environmental correlations between adjacent periods were negative as were the environmental correlations between weaning weight and early post-weaning gains. Errors in weighing, differences in fill at the end of 
different periods and compensatory growth are the reasons put forward by the author to explain the negative sign of these correlations.

In the Simmental breed, a genetic correlation of -0.54 was found by AvERDUNK (1968) between weight at 1 year and gain from 1 year until 500 days. This result suggests that selection on 365-days-weight would favour early maturing bulls with lower subsequent growth while selection on 500-day-weight would favour slow maturing bulls with a higher growth capacity.

KocH et al. (1982a) estimated phenotypic, environmental and genetic correlations for non overlapping 56 days intervals. They found an average phenotypic correlation of +0.16 , an average environmental correlation of -0.03 and an average genetic correlation of +0.77 . The genetic correlations were highest between adjacent intervals and tended to decline for more distant gain intervals (e.g. from 0.81 to 0.51 when the distance increases from 0 to 112 days).

As selection criterion, growth rate is sometimes opposed to weight for a given age. Arguments in favour of growth rate are : 1) the record is made during the test period, while final weight is a function of birth weight, pretest gain and test gain ; 2) selection on weight for age might lead to increased rate of maturity and higher weight at different ages such as birth and maturity. In fact, this will be true if the genetic correlation between mature weight and growth rate is smaller than the correlations between mature weight and final weight (FImLAND, 1973). When pretest environment is not known and owing to the high negative environmental correlation between pretest gain and on-test gain, ToNG (1982) suggests that both weight for a given age and ontest daily gain should be combined in an index, each trait receiving equal emphasis.

More recently, SIMM et al. (1986) recommended, for use in a practical UK improvement programme, an index with the following measurements : growth rate, food conversion efficiency and ultrasonic fat area, the aggregate breeding value comprising growth rate, food conversion efficiency, killing-out proportion and carcass lean proportion. Given the genetic parameters and the economic weights used to construct this index, it is expected that selection based on it would lead to a slight decrease in carcass lean proportion but less than the decrease expected from selection solely on growth rate. These authors consider that measuring food consumption is expensive but worthwhile since dropping this measurement from the index would proportionally reduce the correlation with overall breeding value by 0.14 . On the other hand, but for a dairy population, Fimland (1973) did not include feed conversion in his index considering the high correlation between growth rate and feed conversion and the inaccuracy of its recording. We have seen that a substantial improvement in net added value (and in feed conversion) could be expected without feed intake recording.

By dam and son comparisons, Lickley et al. (1960) found a genetic correlation of +0.64 between daily gain and mature weight. They calculated that selection for daily gain would be $1 / 3$ as effective in increasing mature size as selection for mature size itself. From paternal half-sib analyses, BROWN et al. (1972b) estimated genetic correlations between cow mature weight and gains (in females of the Hereford and Angus breed respectively) between $4-8$ months $(-0.38 ;-0.02)$, between $8-12$ months $(-0.12$; $0.09)$, between $12-16$ months $(0.22 ; 0.46)$ between $16-20$ months $(0.57 ; 0.72)$. The authors concluded from their investigation that gains and weights were not regulated by identical groups of genes and that, as a consequence, selection for large gain or large weights would not effect identical changes in the growth pattern of all individuals. However, mature weight should be increased in case of selection of animals making 
large gains at advanced ages. ANDERSEN (1978) reported a genetic correlation of +0.40 between mature cow weight and daily gain of young bulls at $490 \mathrm{~kg}$ and estimated that an increase of $100 \mathrm{gr}$ in the average daily gain (direct selection) would be followed by and indirect increase of $48 \mathrm{~kg}$ in mature cow weight. Olson et al. (1982) assigned 82 cows to four groups of cow size : weight $(\mathrm{kg})$ (height, $\mathrm{cm}): 451$ (115.6) ; 517 (121.1) ; $567(122.8) ; 647(129.6)$. The means for postweaning growth rate of steers born from these cows were : $1.42 ; 1.48 ; 1.48 ; 1.40(\mathrm{~kg})$ not significantly different. Nevertheless, the preweaning traits (birth weight, age and weaning weight) were significantly different among groups of cow size. MACNEIL et al. (1984) estimated genetic correlations of traits of females with growth traits of their steer paternal halfsibs. The estimate of genetic correlation between daily gain measured on males and mature weight measured on females at 7 years of age was equal to : +0.07 . They calculated that per standard deviation of direct response in daily gain $(+0.126 \mathrm{~kg})$ the predicted correlated response in mature weight would be $+4.0 \mathrm{~kg}$. Analysing estimates of mature weight, rate of maturing and weight from 4 to 36 months within 2 groups of females (Hereford and Angus), Brown et al. (1972a) found an important genetic variation in growth patterns suggesting that, through selection, different patterns of growth could be achieved.

The complex relationships between an animal's genotype and the rearing system and between performances at different phases of growth need to be understood before making the proper choice of selection criteria and testing procedures (feeding system, age of animals, length of test).

\section{Conclusions}

Among the 4 biological types considered, but mainly between the double-muscled type on the one hand and the other 3 types on the other hand, significant differences were found regarding feed intake, feed conversion ratio, carcass composition, selling price and net income after fattening.

Within biological types, feed intake and feed conversion ratio were greatly influenced by initial weight and daily gain but to a small extent by the carcass composition as measured by the dressing-out percentage and the percent lean in the $7^{\text {th }}$ ribcut. Lower maintenance requirements of the double-muscled bsll seem to be the reason for its lower feed intake at equal daily gain.

Among the single traits considered, daily gain and feed conversion ratio had the most pronounced effect on net income, the latter being considered not for the total production system but only for a segment of it, the fattening period of the young. Within the double-muscled type, net income was negatively correlated with initial weight. Selection for higher net income during the fattening period would have as correlated responses a larger growth rate, a lower feed conversion ratio, a decreased initial weight and a slightly increased final weight. Final weight was a poor selection criterion if the objective was to improve net income during the fattening period. The possibility of a genetic manipulation of the growth curve depends on the sign and strength of genetic correlations for growth between adjacent periods. In these data (males fed ad libitum from one month of age, test period from 7 to 12 months) the genetic correlation between initial weight and on-test gain was not significantly different 
from zero. The choice of selection criteria and testing procedures presuppose a good understanding of the relations between growth rates at different ages, for a given rearing system.

Received May 12, 1986.

Accepted November 5, 1986.

\section{References}

ANDERSEN B.B., 1978. Animal size and efficiency, with special reference to growth and feed conversion in cattle. Anim. Prod., 27, 381-391.

Averdunk G., 1968. Genetic aspects of test period length for rate of gain in cattle. J. Anim. Sci., 27, 1124 (Abstr.).

B.I.F., 1981. Guidelines for Uniform Beef Improvement Programs. Beef Improvement Federation. U.S.D.A. Ext. Serv. Program Aid 1020.

Brown J.E., Brown C.J., Burts W.T., 1972a. A discussion of the genetic aspects of weight, mature weight and rate of maturing in Hereford and Angus cattle. J. Anim. Sci., 34, 525-537.

Brown J.E., Brown C.J., BuTts W.T., 1972b. Relationships among weights, gain and earliness of maturing in Hereford and Angus females. J. Anim. Sci., 35, 507-517.

Brown C.J., Johnson Z., Brown A.H., 1986. Some genetic aspects of feed intake, gain and feed conversion of young bulls on postweaning gain test. 3rd World Congress on Genetics applied to Livestock Production, Lincoln, July 16-22, 1986, Agricultural Communications, Vol. XI, 291-295. University of Nebraska, Lincoln.

Cartwright T.C., Dayhoff E.E., 1959. Some factors influencing variation in 28-day gains of feedlot cattle. J. Anim. Sci., 18, 1463 (Abstr.).

Cundiff L.V., Koch R.M., Gregory K.E., Smith G.M., 1981. Characterization of biological types of cattle - cycle II. IV. Post weaning growth and feed efficiency of steers. J. Anim. Sci., 53, 332-346.

Davis M.E., Wilson G.R., Harvey W.R., Turner T.B., 1985. Adjustment of post weaning feed : gain ratios of Angus bulls for differences in maintenance requirements. J. Anim. Sci., 61, 1395-1401.

Dickerson G.E., 1982. Effects of genetic changes in components of growth on biological and economic efficiency of meat production. 2nd World Congress on Genetics applied to Livestock Production, Madrid, October 4-8, 1982, Vol. V, 252-267. Garsi, Madrid.

Dickerson G.E., 1985. Potential uses of genetic variation in components of animal growth. $J$. Anim. Sci., 61 (suppl. 2), 104-117.

Duncan D.B., 1955. Multiple range and mutiple F tests. Biometrics, 11, 1-42.

Ferrel C.L., Jenkins T.G., 1985. Cow type and the nutritional environment : nutritional aspect. J. Anim. Sci., 61, 725-741.

Fimland E.A., 1973. Estimates of phenotypic and genetic parameters for growth characteristics of young potential AI bulls. Acta Agric. Scand., 23, 209-216.

Fitzhugh H.A. Jr., 1976. Analysis of growth curves and strategies for altering their shape. $J$. Anim. Sci., 42, 1036-1051.

Geay Y., Robelin J., Vermorel M., Beranger C., 1982. Muscular development and energy utilisation in cattle : the double-muscled as an extreme or a deviant animal. In : KING J.W.B., MENISSIER F. (ed.), Muscle hypertrophy of genetic origin and its use to improve beef production, 74-87. Martinus Nijhoff, The Hague.

Grossman M., Bohren B.B., 1985. Logistic growth curve of chickens : heritability of parameters. J. Hered., 76, 459-462.

HANSET R., 1982. Muscular hypertrophy as a racial characteristic : the case of the Belgian Blue Breed. In : KING J.W.B., MENISSIER F. (ed.), Muscle hypertrophy of genetic origin and its use to improve beef production, 437-449. Martinus Nijhoff, The Hague.

Hanset R., Stasse A., Michaux C., 1979. Feed intake and feed efficiency in double-muscled and conventional cattle. Z. Tierz. Züchtungsbiol., 96, 260-269. 
Hanset R., Michaux C., 1985a. On the genetic determinism of muscular hypertrophy in the Belgium White and Blue cattle breed. I. Experimental data. Génét. Sél. Evol., 17, 359-368.

Hanset R., Michaux C., 1985b. On the genetic determinism of muscular hypertrophy in the Belgium White and Blue cattle breed. II. Population data. Génét. Sél. Evol., 17, 369-386.

Hanset R., Michaux C., 1986. Characterization of biological types of cattle by the blood levels of creatine and creatinine. J. Anim. Breed. Genet., 103, 227-240.

HaRveY W.R., 1977. User's guide for LSML76. Ohio State University.

Koch R.M., Swiger L.A., Doyle Chambers, Gregory K.E., 1963. Efficiency of feed use in beef cattle. J. Anim. Sci., 22, 486-494.

Koch R.M., CundifF L.V., Gregory K.E., 1982a. Influence of postweaning gain interval on estimates of heritability and genetic correlations. J. Anim. Sci., 55, 1310-1318.

Koch R.M., Gregory K.E., CundifF L.V., 1982 b. Critical analysis of selection methods and experiments in beef cattle and consequences upon selection programs applied. 2nd World Congress on Genetics applied to Livestock Production, Madrid, October 4-8, 1982, Vol. V, 514-526. Garsi, Madrid.

Lickley C.R., Stonaker H.H., Sutherland T.M., RidDle K.H., 1960. Relationship between mature size, daily gain and efficiency of feed utilization in beef cattle. J. Anim. Sci., 19, 957 (Abstr.).

Macneil M.D., Cundiff L.V., Dinkel C.A., Koch R.M., 1984. Genetic correlations among sexlimited traits in beef cattle. J. Anim. Sci., 58, 1171-1180.

Michaux C., Stasse A., Sonnet R., Leroy P., Hanset R., 1983. La composition de la carcasse de taureaux culards Blanc-Bleu belge. Ann. Méd. Vét., 127, 349-375.

Olson L.W., Peschel D.E., Paulson W.H., Rutledge J.J., 1982. Effects of cow size on cow productivity and on calf growth, postweaning growth efficiency and carcass traits. J. Anim. Sci., 54, 704-712.

Preston T.R., Willis M.R., 1974. Intensive Beef Production. 2nd Edition, 567 pp., Pergamon Press, Oxford.

PyM R.A.E., 1982. Selection results for efficiency of food utilization in livestock and poultry. 2nd World Congress on Genetics applied to Livestock Production, Madrid, October 4-8, 1982, Vol. V., 231-244. Garsi, Madrid.

Robertson A., 1982. Genetic aspects of growth. Proceedings of the World Congress on Sheep and Beef Cattle Breeding, Palmerston North, October 28-November 13, 1980, BARTON R.A., SMITH W.C. (ed.), Vol. I, 427-437. The Dunmore Press Limited, Palmerston.

Simm G., Sмith C., Prescott J.H.D., 1986. Selection indices to improve the efficiency of lean meat production in cattle. Anim. Prod., 42, 183-193.

Smith G.M., Laster D.B., CundifF L.V., Gregory K.E., 1976. Characterization of biological types in cattle. II. Postweaning growth and feed efficiency of steers. J. Anim. Sci., 43, 37-47.

Snedecor G.W., Cochran W.G., 1980. Statistical Methods. 7th Edition, 507 pp., Iowa State University Press, Ames, U.S.A.

Swiger L.A., 1961. Genetic and environmental influences on gain of beef cattle during various periods of life. J. Anim. Sci., 20, 183-188.

Thompson J.M., BARLow R., 1986. The relationship between feeding and growth parameters and biological efficiency in cattle and sheep. 3rd World Congress on Genetics applied to Livestock Production, Lincoln, July 16-22, 1986, Agricultural Communications, Vol. XI, 271-282. University of Nebraska, Lincoln.

Tong A.K.W., 1982. Effects of initial age and weight on test daily gains of station-tested bulls. Can. J. Anim. Sci., 62, 671-678.

VAlis-Ortiz J.M., Menissier F., VisSAC B., 1972. Etude du caractère culard. VI. Transmission et possibilités d'utilisation en croisement de première génération pour la production de veaux de boucherie. Ann. Génét. Sél. Anim., 4, 7-28.

Vermorel M.J., Bouvier C., Geay Y., 1976. The effect of genetic type (normal and doublemuscled Charolais and Friesian) on energy utilization by growing cattle at 2 and 16 months of age. Vermorel M.J. (ed.), Proc. 7th Symp. Energy Metabolism. Eur. Assoc. Anim. Prod., Publ. $n^{\circ}$ 79, 217-221. G. de Bussac, Clermont-Ferrand, France.

Webster A.J.F., 1985. Differences in the energetic efficiency of animal growth. J. Anim. Sci., 61 (Suppl. 2), 92-103. 